\title{
Effect of 3D Animation-Assisted Education on Knowledge Level of Nursing Students for the Evaluation of Respiration
}

\author{
3D Animasyon Destekli Ĕ̆itimin Hemşirelik Ö ̆̆rencilerinin \\ Solunumun Değerlendirilmesine Yönelik Bilgi Düzeylerine Etkisi
}

\author{
Berna DİNCER $^{1} \oplus$, Cemile SAVCI $^{1} \oplus$, Hasan Hüseyin MUTLU $^{2} \odot$ \\ ${ }^{1}$ İstanbul Medeniyet Üniversitesi, Să̆lık Bilimleri Fakültesi, Hemşirelik Bölümü, İstanbul, Türkiye \\ ${ }^{2}$ İstanbul Medeniyet Üniversitesi, Tip Fakültesi, Temel Tip Bilimleri, İstanbul, Türkiye
}

\section{ABSTRACT}

Objective: This study has been performed to determine the effect of 3D animation-assisted education, which was developed for nursing students and designed to evaluate on knowledge level of the students on respiration.

Methods: This study was designed as a randomized controlled experimental study consisting of pretest and posttest sections. The sample of the study consisted of sixty $2^{\text {nd }}$ grade nursing school students of a state university in Istanbul who met the research criteria and agreed to participate in the research in the 2018-2019 academic year, "Information Form" including sociodemographic features and "Knowledge Test for Evaluation of Respiration" measuring knowledge level on the evaluation of respiration were used as data collection tools. The research study was conducted in two stages as preparation and application. Preparation stage included determination of learning goals, selection of $3 D$ animations to be used, preparation of the guidelines for evaluation of respiration, and preparations of the educator and students.

Results: In the study, it was found that the mean posttest scores of the students in the experimental group were higher compared to the students in the control group, and there was a significant difference between posttest scores of the two groups $(p<0.01)$.

Conclusion: The results indicated that combination of the traditional education method and $3 D$ animation-assisted education might have effect on knowledge level of nursing students about the evaluation of respiration.

Keywords: Nursing education, 3D animation, knowledge öz

\begin{abstract}
Amaç: Bu araștırma, hemșirelik öğrencileri için gelistirilen ve solunumun de ğerlendirilmesine yönelik tasarlanan $3 D$ animasyon eğitiminin öğrencilerin bilgi düzeylerine etkisini belirlemek amacıyla yapılmıştır.

Yöntem: Araştırma, ön test - son testten oluşan randomize kontrollü deneysel bir çalısmadır. Araştırmanın örneklemi$n i$, İstanbul ilinde bir devlet üniversitesinin 2018-2019 ĕgitim ögrretim yılında hemşirelik bölümünün 2. sinıfında ögrenim görmekte olan, araștırma kriterlerine uyan ve araştırmaya katılmayı kabul eden 60 öğrenci oluşturmuştur. Veri toplama aracı olarak, sosyodemografik özellikleri içeren "Bilgi Formu”, solununum değerlendirilmesine yönelik bilgi düzeyini ölçen "Solunum Değerlendirilmesine Yönelik Bilgi Testi” kullanılmıştır. Araştırma, hazırlık ve uygulama olmak üzere 2 aşamada gerçekleştirilmiştir. Araştırmanın hazırlık aşaması, öğrenim hedeflerinin belirlenmesini, 3D animasyonların seçimi, solunumun değerlendirilmesine yönelik kılavuzların hazırlanmasını, eğitimci ve ögrenci hazırlıklarını içermektedir.

Bulgular: Araştırmada, deney grubundaki öğrencilerin son test puan ortalamalarının, kontrol grubundaki öğrencilere oranla daha yüksek olduğu, iki grubun son test puanları arasında anlaml farklılık bulunduğu saptanmıştır $(p<0.01)$.

Sonuç: Bulgular, geleneksel eğitim yöntemi ile 3D animasyon destekli eğitimin birlikte kullanımının, solunum fonksiyonunun de ğerlendirilmesinde hemşirelik ögrencilerinin bilgi düzeylerine olumlu etkisi olabileceğini göstermiştir.
\end{abstract}

Anahtar kelimeler: Hemşirelik eğitimi, 3D animasyon, bilgi

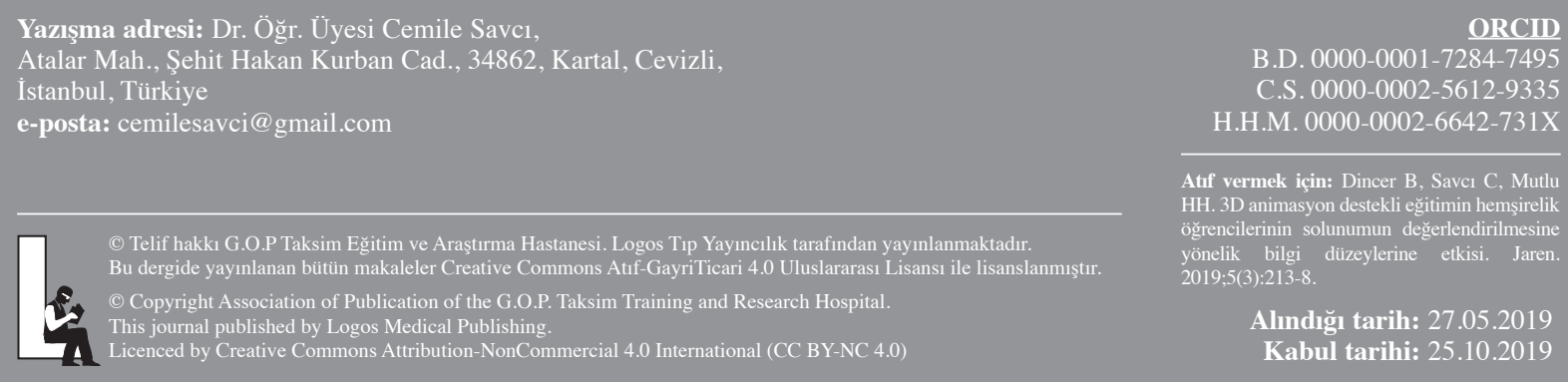




\section{INTRODUCTION}

The most important function of respiratory system is to supply oxygen which is needed by the body and to expel carbon dioxide. It is necessary to evaluate sophistically the respiratory system in order to understand normal and abnormal data about this system. The evaluation of respiratory system requires firstly taking history, then obtaining medical data with inspection, palpation, percussion and auscultation, and planning an appropriate care. Constitution of the knowledge and skills for regular evaluation of the respiratory system findings and interpretation of the data obtained is important for nursing ${ }^{(1)}$.

Because nursing is a profession concerning with understanding cognitive, psychomotor, and attitudinal behaviours, the use of innovative applications in education is crucial. With the improved technology, the importance of use and development of new learning tools is gaining momentum in nursing education ${ }^{(1)}$.

When conducted in a planned way, education technologies provide benefit for educators and students. Education technologies provides equality of opportunity in education by allowing educators and students to have a course when they want, free studying, to use primary resource and the information acquired from the primary resource whenever they want, and by promoting the enhanced and improved education countrywide and even worldwide. Education technologies provide diversity and quality by contributing to individual and mass group learning, creativity by assuming a supportive role in introduction of a new and original product; a productive and fast education by offering students an individualized education based on their interest and skills, and targeted, effective and lasting learning; real learning experiences by preparing an environment for students to learn with practice; lifelong learning by allowing students to access information whenever they want; and creating an environment so as to play active roles by enabling students reaching to information by themselves ${ }^{(2)}$.

These improvements in technology and education, have resulted in association of these two areas, by providing opportunity to use simulation applications, 3D animation-assisted education and tools that are among the commonly used, reliable education methods in raising technical and non-technical skills in nursing education ${ }^{(1,3-5)}$. In nursing education, it is necessary to prepare the students for the future, to support the development of their professional life, to integrate information technologies and different training methods into nursing education programs for qualified and safe nursing care ${ }^{(6,7)}$. It is thought that the use of 3D animations in nursing education will enable education with enhanced visual content, providing learning facilities by offering different learning media to students, and encouraging development of their clinical decision-making skills. Utilization, and extending the application area of 3D animation-assisted education method in nursing is recommended in the literature since it contributes to cognitive development of the students ${ }^{(1,3-5)}$.

Within this context, it is thought that $3 \mathrm{D}$ animationassisted education method will offer students a new point of view as an alternative to traditional education methods. The objective of this study was to determine effect of 3D animation education, which was developed for nursing students and designed to evaluate knowledge level of the students on respiration.

\section{METHODS}

\section{Study Design and Sampling Method}

This study was designed as a randomized controlled experimental study consisting of pretest and posttest parts. Sample of the study consisted of 60 students (experiment $n=30$, control $n=30$ ) who received education in grade 2 of nursing department of a public university in 2018-2019 academic year, and fulfilled the inclusion criteria, and agreed to participate in the study. Volunteered students who were receiving Medical Nursing Course for the first time, and did not graduate from vocational school of health without any knew language, and communication barrier were included in the study.

\section{Data collection}

"Information Form" including sociodemographic features and "Knowledge Test for Evaluation of Respiration" measuring knowledge level on the evaluation of respiration were used as data collection tools. 


\section{Information Form}

This form prepared by the researchers in line with the literature contained questions investigating sociodemographic features of the students.

Knowledge Test for Evaluation of Respiration: The test form contained 20 multiple-choice questions with 5 options. Each question was valued at 5 points. The maximum total score was 100 points. Content validity of the test was provided in line with opinions of three specialists, one of them being a faculty member in the Department of Nursing Fundamentals, one member from the Department of Measurement and Evaluation in Education, and one member from the Department of Medical Education and Informatics.

\section{Ethical Considerations}

Study data were collected after receiving ethics committeeapproval(B.08.6.YÖK.2.ÜS.0.05.0.06/2018/518) and institutional permission from the university. The students were informed about the study and included after obtaining their written consent.

\section{Data Analysis}

Data obtained from the study were analyzed using SPSS ${ }^{2} 21.0$ (Statistical Package for the Social Science) statistical package software. Data were not normally distributed according to Shapiro Wilks test. Percentage distribution and medium (min-max) were used in the analysis of sociodemographic data of the students. Since the data were not normally distributed, Mann Whitney-U and Wilcoxon Ranks tests were used. Level of statistical significance of the data was considered as $\mathrm{p}<0.05$ and evaluated at $95 \%$ confidence interval.

\section{Study Period}

For the randomization of the patients evenly (experiment $n=30$, control $n=30$ ), the students were asked to select randomly from the cards written 'experiment' or 'control' on them. The study was conducted in two stages as preparation and application. Preparation stage included determination of learning goals, selection of 3D animations, preparation of the guidelines for the evaluation of respiration, and the educators and students for the study (Flow chart).

In the preparation stage of the study, goal and learning outputs of the education, and 3D animation videos were priorly determined. The experiment and control groups were educated on the evaluation of respiration using traditional method. PowerPoint presentation and verbal narration techniques were used for educational purposes.

For 3D animation, the videos to be used were determined by the researchers in line with the relevant literature. The content of 3D animation video was selected so as to meet the targets of ability to begin and maintain communication with the patient about evaluation of respiration, to collect data about complaints of the patient, to perform physical examination and make interpretation. Guidelines were prepared in the preparation stage in order to facilitate conformity of the educator and students. The guidelines included rational objective methods, schedule of the study and informed consent form. Information meeting was held for preparations of the students to inform them about the objective and process of the study.

\section{RESULTS}

Study group consisted mostly $(81.7 \%)$ of female students, the mean age of the study group was $19.41 \pm 0.88$ years. No significant difference was found between mean success rates of the students in the experimental and control groups (Table 1).

Table 1. Success averages of the students $(\mathrm{N}=60)$.

\begin{tabular}{lcccc}
\hline & \multicolumn{2}{c}{ Groups } & & Test Value \\
\cline { 2 - 3 } & & $\begin{array}{c}\text { Experimental } \\
(\mathbf{n}=\mathbf{3 0})\end{array}$ & $\begin{array}{c}\text { Control } \\
(\mathbf{n}=\mathbf{3 0})\end{array}$ & $\mathbf{P}$ \\
\hline $\begin{array}{l}\text { Success } \\
\text { Averages }\end{array}$ & Mean \pm SD & $2.67 \pm 0.29$ & $2.55 \pm 0.36$ & 0.37 \\
\hline
\end{tabular}

Mean scores received by the experimental and control groups from the knowledge test for the evaluation of respiration were calculated (Table 2). No statistically significant difference was found between the groups in terms of pretest mean scores $(\mathrm{p}>0.05)$. However, posttest mean scores were higher in the experimental group compared to the control group, and there was a significant difference between the posttest mean scores of the two groups $(\mathrm{p}<0.01)$. The students in both groups received maximum scores from the posttest (Table 2). 
Table 2. Mean scores of the knowledge test for evaluation of respiration $(\mathrm{N}=60)$.

\begin{tabular}{|c|c|c|c|c|}
\hline \multirow[b]{2}{*}{$\begin{array}{l}\text { Knowledge } \\
\text { test for } \\
\text { evaluation } \\
\text { of } \\
\text { respiration }\end{array}$} & & \multicolumn{2}{|c|}{ Groups } & \multirow{2}{*}{$\frac{\text { Test Value }}{\mathbf{P}}$} \\
\hline & & $\begin{array}{c}\text { Experimental } \\
(\mathbf{n}=\mathbf{3 0})\end{array}$ & $\begin{array}{c}\text { Control } \\
(\mathbf{n}=30)\end{array}$ & \\
\hline Pretest & Mean \pm SD & $68.66 \pm 13.57$ & $70.16 \pm 13.54$ & $\begin{array}{c}\mathrm{Z}:-.463 \\
\mathrm{a}=643\end{array}$ \\
\hline Posttest & Mean \pm SD & $84.16 \pm 8.31$ & $72.50 \pm 13.56$ & $\begin{array}{c}\mathrm{Z}:-3.438 \\
\text { a } .001^{*}\end{array}$ \\
\hline $\begin{array}{l}\text { Posttest- } \\
\text { Pretest }\end{array}$ & $\begin{array}{l}\text { Difference } \\
\text { Test Value } \\
\mathrm{p}\end{array}$ & $\begin{array}{c}15.50 \pm 11.54 \\
\mathrm{Z}:-4.482 \\
\text { '.000* }\end{array}$ & $\begin{array}{c}2.33 \pm 3.65 \\
\mathrm{Z}:-2.977 \\
\text { '.003* }\end{array}$ & $\begin{array}{c}\text { Z: }-4.379 \\
\text { a } .000^{*}\end{array}$ \\
\hline
\end{tabular}

${ }^{a}$ Mann Whitney U Test, ${ }^{b}$ Wilcoxon Ranks Test, * $p<0.01$

A statistically significant intragroup change was detected between the experimental and the control groups as for pretest and posttest mean scores $(\mathrm{p}<0.01)$.

\section{DISCUSSION}

Nursing education aiming to provide nurses with improved cognitive, psychomotor, and attitudinal behaviours requires the use of an education system and innovative applications covering learning areas for psychomotor, and attitudinal behaviours enough for students to assume specified roles ${ }^{(1,8)}$. Educational animations are among the multimedia tools playing an important role in education in the health sector ${ }^{(9,10)}$. 3D animations are stated to be effective multimedia tools especially in teaching human anatomy and physiology in medical education ${ }^{(11)}$. Although some authors have investigated the use and positive effects of 3D animated videos in nursing education, the number of studies showing the role of the 3D animated videos in education of nursing studies is limited. In a university from Scotland, improved outcomes were achieved with the use of multimedia in teaching nursing skills ${ }^{(12)}$. Similarly, in another study it was found that videos showing drug management were perceived as good practice tools by nursing students ${ }^{(13)}$.

In this study which was conducted to determine the effect of 3D animation education designed for the evaluation of knowledge levels of mostly female nursing students on respiration, school success averages were similar, indicating that the groups were similar in this respect (Table 1).
Studies have reported that combined use with an innovative education system (e-learning, simulation, 3D animation etc.) rather than face-to-face traditional method will be more effective in raising knowledge level of students ${ }^{(13-15)}$. Within this context, in this study conducted to determine effectiveness of the education on knowledge levels required for the evaluation of respiration between the nursing students who received 3D animation-assisted education combined with the traditional method and the students who received traditional education alone (PowerPoint technique and verbal narration); there was a significant difference between the groups in terms of posttest mean scores, and the mean scores were higher in the students who received 3D animation-assisted education (Table 2: $\mathrm{p}<0.01$ ). In line with this result, it can be said that the use of 3D animation-assisted education positively affected quality of education given for nursing students. In a study by Pandey ${ }^{(13)}$ it was reported that $3 \mathrm{D}$ animation-assisted briefing followed by practice, improved learning in nursing students. In a study by Akin Korhan et al. ${ }^{(8)}$, students stated that watching the videos before skills laboratory practice, facilitated and supported their learning.

\section{CONCLUSION}

Results of this study have indicated that the combined use of traditional education method (PowerPoint technique and face- to- face verbal narration) with 3D animation assisted education may have positive effects on knowledge levels of nursing students for the evaluation of respiration.

As a limitation, we included only studies receiving education in grade two of the nursing school. Further studies with larger samples comparing the different grades of the nursing school will promote the research on this issue.

\section{ACKNOWLEDGEMENT}

We would like to thank to the students for participating in the study and the academic personnel for their support. 


\section{Flow Chart}

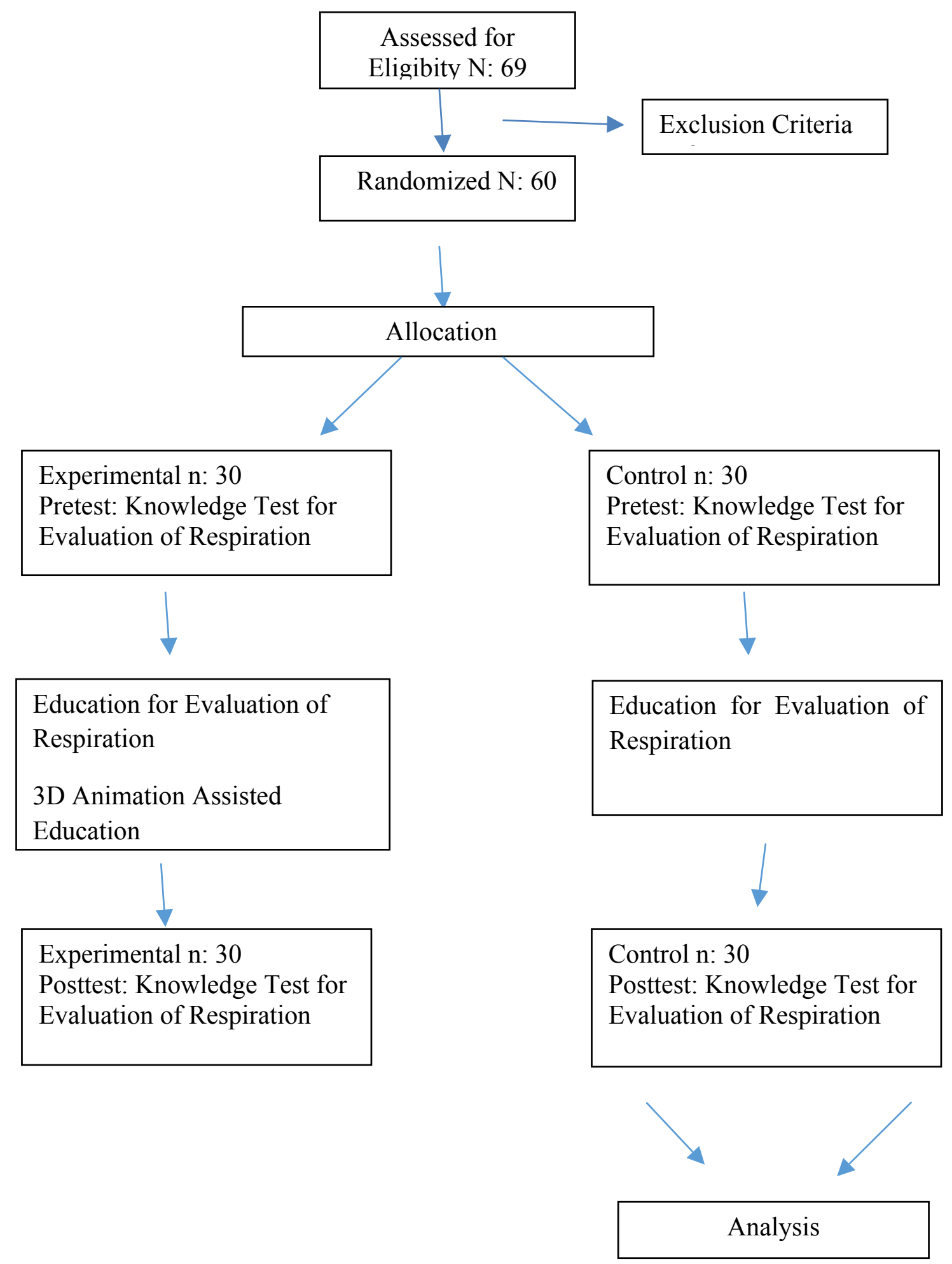


Ethics Committee Approval: S.B. Istanbul Medeniyet University Goztepe Training and Research Hospital Ethics Committee approval was obtained (2018/0520).

Conflict of Interest: There is no conflict of interest related to any person and/or institution.

Funding: No financial support was received from any institution/organization during the research process.

Informed Consent: The participants were informed about the research and their written informed consent was obtained.

Etik Kurul Onayı: S.B. İstanbul Medeniyet Üniversitesi Göztepe Eğitim ve Araştırma Hastanesi Klinik Araştırmaları Etik Kurulu onayı alınmıştır (2018/0520).

Çıkar Çatışması: Herhangi bir kişi ve/veya kurum ile ilgili çıkar çatışması yoktur.

Finansal Destek: Araştırma sürecinde hiçbir kurum/ kuruluştan finansal destek alınmamıştır.

Hasta Onamı: Katılımcılar araştırma hakkında bilgilendirildi ve yazılı onamları alındı.

\section{REFERENCES}

1. Göriş S, Bilgi N, Bayındır SD. Hemşirelik eğitiminde simülasyon kullanımı. Düzce Üniversitesi Sağlık Bilimleri Enstitüsü Dergisi. 2014;4(2):25-9.

2. İşman A. Öğretim Teknolojileri ve Materyal Geliştirme. İstanbul: Değişim Yayınları; 2003.

3. Bremner MN, Aduddell K, Bennett DN, VanGeest JB. The use of human patient simulators best practices with novice nursing students. Nurse Educator. 2006;31(4):170-4. [CrossRef]

4. Moule P, Wilford A, Sales R, Lockyer L. Student experiences and mentor views of the use of simulation for learning. Nurse Education Today. 2008;28(7):790-7. [CrossRef]
5. Altun E, Ateş A. İletişim Teknolojileri. İçinde: Demirel Ö,Altun E, edt. Ö ğretim Teknolojileri ve Materyal Tasarımı. 7. bask1. Ankara: Pegem Akademi; 2012.

6. Şendir M, Coşkun EY. Hemşirelik eğitiminde teknolojik bir adım: IMventro-sim. JAREN. 2016;2(2):103-8.

7. Işık BT, Kaya HT. Bilgi ve iletişim teknolojilerinin öğretme-öğrenme sürecine entegrasyonunda hemşire eğitimcilerin rolü. İstanbul Üniversitesi Florence Nightingale Hemşirelik Yüksekokulu Dergisi. 2011;19(3):203-9.

8. Akın Korhan E, Tokem Y, Uzelli Yılmaz D, Dilemek H. Hemşirelikte psikomotor beceri eğitiminde video destekli ögretim ve OSCE uygulaması: bir deneyim paylaşımı. İzmir Katip Çelebi Üniversitesi Sağlık Bilimleri Fakültesi Dergisi. 2016;1(1):35-7.

9. Jang HW, Kim KJ. Use of online clinical videos for clinical skills training for medical students: benefits and challenges. BMC Medical Education. 2014;14(1):56. [CrossRef]

10. Yue C, Kim J, Ogawa R, Stark E, Kim S. Applying the cognitive theory of multimedia learning: an analysis of medical animations. Med Educ. 2013;47(4):375-87. [CrossRef]

11. Hoyek N, Collet C, Di Rienzo F, De Almeida M, Guillot A. Effectiveness of three-dimensional digital animation in teaching human anatomy in an authentic classroom context. Anatomical Sciences Education. 2014;7(6):430-7. [CrossRef]

12. Chiang HC, Lin FY, Hwu YJ. Disability assessment: the efficacy of multimedia interactive nurse education. $\mathrm{J}$ Nurs Res. 2013;21(2):83-93. [CrossRef]

13. Pandey N. Impact of 3-D animation assisted practical teaching in nursing students. Journal of Education Technology in Health Sciences. 2015;2(3):90-3.

14. Gu Y, Zou Z, Chen X. The effects of vSIM for nursing as a teaching strategy on fundamentals of nursing education in undergraduates. Clinical Simulation in Nursing. 2017;13(4):194-7. [CrossRef]

15. Sheikhaboumasoudi R, Bagheri M, Hosseini SA, Ashouri E, Elahi N. Improving nursing students' learning outcomes in fundamentals of nursing course through combination of traditional and e-learning methods. Iranian Journal of Nursing and Midwifery Research. 2018;23(3):217. [CrossRef] 